\title{
Malini Roy
}

Independent scholar, Frankfurt am Main, Germany

roym26@gmail.com

\section{The Vanished Path of Buddhism: Religious Non-Conformism as Political Dissent in Contemporary India}

Izvorni znanstveni rad / original research paper

Primljeno / received 23. 12. 2016. Prihvaćeno / accepted 13. 10. 2017.

DOI: 10.21066/carcl.libri.2017-06(02).0001

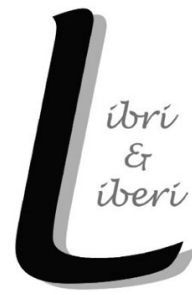

This paper takes a close look at the graphic novel The Vanished Path (2015) by comics artist and filmmaker Bharath Murthy. Sub-titled as "a graphic travelogue", The Vanished Path relates Murthy and his wife's pilgrimage, as new entrants to the Buddhist faith, through Hindu-dominated northern India and Nepal, where the religion was born but later lost popularity. Murthy himself acknowledges the influence of manga author Osamu Tezuka's epic series Buddha (1972-1983), set in the era of early Buddhism. However, The Vanished Path departs from Buddha in engaging with religious politics in contemporary India, which has witnessed the recent rise of Hindu militant nationalism. My analysis shows that while the visual text of The Vanished Path presents an overt plea for rehabilitating early Buddhist thought in modern India, the visual text concurrently encodes a covert defence of the longstanding tradition of secular values in the region. This tradition encompasses the acceptance of religious minorities. The paper also addresses creative engagements in comics and graphic novels between two different Asian cultures, as opposed to the critically familiar historical and geopolitical nexus between Western countries and India.

Keywords: Hindu nationalism, history of Buddhism, India, religious conflict, secular

The figure of the Buddha, apparently lying in a sleeping position and bathed in an aura of golden, tawny, and sepia washes in watercolour, can be seen in the cover illustration of The Vanished Path: A Graphic Travelogue (Fig. 1). This book was written and illustrated by Indian comic artist and filmmaker Bharath Murthy, and published in 2015 by HarperCollins India. The cover illustration is a reproduction of a black-and-white drawing within The Vanished Path, showing a 6.1-metre-long statue of the Buddha "carved out of red sandstone" - hence the distinctive hues in the cover 
illustration - from "the fifth century" at the town of Kushinagar in northern India. The statue is supposed to represent "the exact position that [the Buddha] is reported to have died in, at this location" (Murthy 2015a: 59-60).

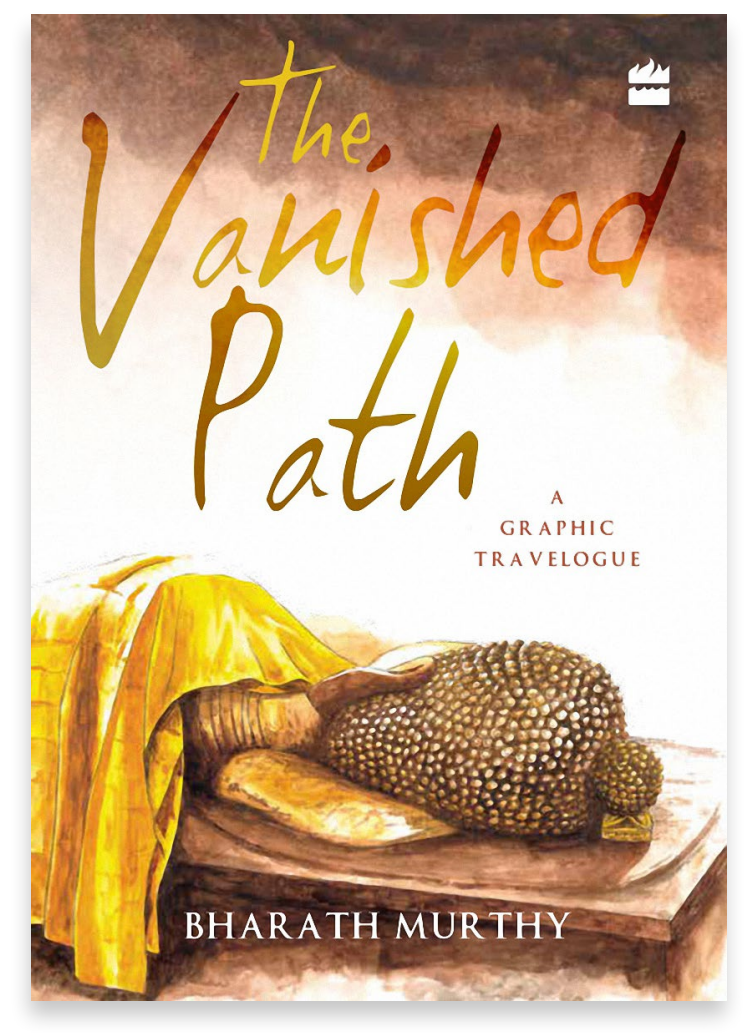

Fig. 1. Front cover of The Vanished Path: A Graphic Travelogue ${ }^{1}$ Sl. 1. Naslovna stranica djela The Vanished Path: A Graphic Travelogue ${ }^{2}$

This sculptural representation of the Buddha's death may also be said to be emblematic of the historical disappearance of the religion of Buddhism in India around the twelfth century AD, which forms the subject matter of The Vanished Path. The "vanished path" in the title of the text refers to the dusky trail of early historic sites of Buddhism extending through northern India and Nepal, where the religion was born, although the faith later spread to other regions including Sri Lanka, and swept across

1 We are grateful to Bharath Murthy in India for giving Malini Roy permission to include the pictures and other fragments from The Vanished Path: A Graphic Travelogue (2015) in her paper to be published in both printed and electronic versions of this issue of Libri \& Liberi.

2 Zahvalni smo Bharathu Murthyju iz Indije na ustupanju autorskih prava Malini Roy za objavljivanje slika i drugih dijelova iz svojega grafičkoga romana The Vanished Path: A Graphic Travelogue (2015) u njezinu radu u tiskanoj i elektroničkoj inačici ovoga broja časopisa Libri \& Liberi. 
large parts of Central, East, and South-East Asia (Lopez, Jr. 2002: 165-170). The subtitle of The Vanished Path, "a graphic travelogue", pictorially betokens the travels of the author himself, delineated by his first name, Bharath, and his wife, Alka. Being novitiates to the Buddhist faith, the two protagonists visit the historic sites in northern India and Nepal associated with the beginnings of Buddhism. The protagonists travel in the spontaneous and meandering style of backpackers, imbibing ground-level experiences differing from those commonly found in comfort travel. Frequently, the protagonists observe and learn about local history and traditions from random strolls as well as visits to roadside cafes and eateries. As an autobiographical work of nonfiction, the travelogue presents the protagonists' attempts at making meaning of the archaeological remains associated with the birth, enlightenment, teachings, monastic guidelines, and the death of the Buddha (Murthy 2015a).

The Vanished Path was generally greeted with the approval of the reading public soon after the book's release: newspaper and magazine reviews, and interviews offered a number of critical insights which I will summarise here briefly. One of the reviewers deftly highlighted, for instance, the narrative of künstlerroman embedded within the progressive elegance of Murthy's artwork in the travelogue: while the initial images in the text possess an "ad hoc" quality to the drawing, those in the later parts appear to evince a greater "sureness of hand" (Desai 2015). Elsewhere, readings of the travelogue pointed to the dramatic interplay between the objective and subjective layers of the protagonists' experiences in their travels, as well as the autobiographical animus of Murthy's religious faith in his turn to Buddhism (Desai 2015; Dundoo 2015; Khanna 2015; Trivedi 2015). Some attention was also paid to doctrinal differences between the religions of Hinduism and Buddhism as represented in The Vanished Path, especially in terms of the influence of Japanese manga author Osamu Tezuka's ten volumes of Buddha (1972-1983) on Murthy's work. This point was well raised: in his list of "Acknowledgements" in The Vanished Path, Murthy himself cheerfully pays homage to Osamu Tezuka's magnum opus, which is an epochal work of hagiography tracing Buddhism's beginnings in early Indian civilization (Murthy 2015a: no page). Osamu Tezuka's work, characterised by social realism, depicts the hierarchical structure of the Hindu caste system in early Indian civilisation, and the consequent historical operations of elitism and discrimination. The first volume of Buddha depicts the "vain and decadent" tendencies within the uppermost priestly caste of the Brahmins, the oppression of people on the lower rungs of the caste ladder, the rise of Buddhism as an egalitarian reformist response to "Brahmin shamming", and a search for "alternate paths to happiness and peace of mind" (Tezuka 1972/2006: 16; cf. Desai 2015; cf. Trivedi 2015).

However, I would suggest that while Osamu Tezuka's Buddha certainly remains a formative influence on The Vanished Path, Murthy also departs boldly from his artistic predecessor in situating a significant part of his narrative not in societies of long ago, but rather in the here and now of the contemporary Indian civil polity. Indeed, Tezuka's ascription of causes for the erstwhile popularity of Buddhism harks back to conflicts 
associated with religion - with caste discrimination as a synchronous evil - that continue to define and mottle public life on the Indian subcontinent (with due modification, given the passage of at least two millennia after the spread of Buddhism). Tezuka's views in Buddha largely concur with those of historian Romila Thapar. In a scholarly article, representative of her position as a public intellectual with a left-liberal bent, Thapar issues a portent about the late-twentieth century emergence of a militant-minded "new Hinduism" in India. She contends that this "new Hinduism" is underpinned ideologically by an "imagined Hindu identity from the past", predicating her argument theoretically upon Benedict Anderson's premise of "imagined communities" that underpin the construct of the nation (Thapar 1989: 210, 215, 228; cf. Anderson 1983). Positing that Hinduism was never a monolithic and homogeneous religion in ancient India, Thapar positions Buddhism at the other end of the same socio-cultural spectrum. According to Thapar, on the one hand, one may observe the Hindu "Brahmanism" of priestly and other upper castes with "high social and economic status", who adhered to the scriptural texts of the Vedas, and associated rituals and social practices. On the other side lies the "Śramanism" of Buddhists, Jains, and sundry sects (including those with Hindu belief systems), which was doctrinally distinct from "Brahmanism" and was reputed to have welcomed all castes into the fold (214-215, 219-220). Thapar's argument is topically relevant to The Vanished Path, given that Hindus form the dominant religious group in India today, while practising Buddhists constitute a small minority (Population 2011).

Thapar's argument has been echoed in recent scholarly studies on South Asia and public discussions in independent media, where commentators have frequently observed and bemoaned the rising cultural cachet of a monopolist "Hindu Nation", predicated on the coercive and occasionally abrasive repression of dissident identities and voices. Such repression, traced for instance by scholars Wendy Doniger and Martha C. Nussbaum in the edited collection Pluralism and Democracy in India (2015), ranges through varied manifestations. These include an infamous pogrom by Hindu nationalists against the Muslim population in inter-religious riots in the western Indian state of Gujarat in 2002, the brazen rewriting of school textbooks in public education, kowtowing to the newly received ideology of the Hindu nation, and the official imposition of bans in a number of states in India on the consumption of beef, commonly taboo for upper-caste Hindus, and consumed mainly by the Muslim population and other religious communities, or indeed Hindus aligned with the religion in name but not necessarily in faith (Doniger \& Nussbaum 2015; Mander 2015: 167-174, 191-196; cf. Daniyal 2015, 2016; Ilaiah 2015). This militant variety of Hinduism has been under scrutiny in international public discussion as well, as observed in an influential article in The Economist which flags, in recent times, a contemporary wave of chauvinistic "new nationalism" across wealthy and newly prosperous countries in the world including the USA, the UK, France, India, China, and Turkey ("The New Nationalism" 2016).

Contrapuntally, the recent upsurge of Hindu militant nationalism in India may be contrasted against a strong tradition of secular thinking in the region that is engraved in the Indian Constitution (as discussed below) but also extends back to ancient times, as 
articulated by public intellectual Amartya Sen. In The Argumentative Indian - a study of the history of ideas on the Indian subcontinent - Sen has pointed to the "tolerance of religious diversity" being "implicitly reflected in India's having served as a shared home - in the chronology of history - for Hindus, Buddhists, Jains, Jews, Christians, Muslims, Parsees, Sikhs, Baha'is and others" (2005: 16-17). Sen asserts the abiding "strength of scepticism in India, which extends to religions as well, particularly in the form of doubting the relevance of religious beliefs in political affairs" (72).

Given the tug-of-war between sectarian and secular politics in contemporary India, I would suggest that The Vanished Path is more ambitious in scope than existent reviews have suggested in terms of the text's engagement with issues of religious conflict. In view of the timing of the text's publication, this article aims to establish that in presenting an overt and sober plea for rehabilitating early Buddhist thought in modern India, the visual text of The Vanished Path concurrently encodes a covert and assured defence of secular values, which encompasses the acceptance of religious minorities. The visual text asks for the dominant majority's disavowal of physical violence as well as "epistemological violence" towards the Other, to borrow a term from the social sciences (cf. Teo 2010).

In fact, Murthy's creative output preceding The Vanished Path has developed and sustained a longstanding dialogue with the medium of Japanese manga. In 2010 he filmed a documentary about doujinshi or the sub-culture of self-published manga for NHK, the Japanese broadcasting corporation, entitled The Fragile Heart of Moé (2010). For his own short-length comics Murthy produced before The Vanished Path - published in national dailies like The New Indian Express and self-published webcomics he drew upon his direct and intimate knowledge of manga produced in Japan, gained through his film-making experiences (Murthy 2016). In reflecting on his own aesthetic practices as well, Murthy has articulated his strong affinity towards Japanese manga by establishing theoretical grounds for his preference, which he has polemicised in discursive essays posted on his blog and in email interviews. ${ }^{3}$ In a graphic essay entitled "A Form of Writing: An Essay on the Comic" (2011), Murthy contrasts the Japanese manga One Piece by Eiichiro Oda with panels from an American comic book featuring Wonder Woman, one of the (oddly female) superheroes popularised by industry giant DC Comics. Murthy extrapolates that the artwork of Japanese manga typically displays a tendency towards "abstraction" as contrasted with the "realistic" bent of American comic books (2011: no page). According to Murthy, the abstract qualities of Japanese manga inhere in a bias towards "black and white images" and visual texts characterised by a "2-dimensional" arrangement of "space", comprising "simplified cartoon drawing" and "flat shapes". The panels are divided in a "non-linear" manner, which means that the "narrative is grasped not by linear progression of action but by the cumulative effect of the entire page. The eyes need to take in the entire page at once". By contrast, Murthy maintains that artwork in colour forms the norm in American comic books. Spatial arrangements tend to be three-dimensional: characteristics include an "illusion

3 Emails from Bharath Murthy to author (16 April 2011, 5 May 2011). 
of depth", an emphasis on "shading rather than lines" and the phenomenon of "figure drawing". Discrete "[p]anels are divided to represent consecutive actions, in a linear way", and the reader's "eyes follow each panel separately" as the narrative develops in sequence. These characteristics appear to be rooted in the visual culture of perspectival representation, initiated, as observed by comics scholar and author Santiago García, in the 1930s by American adventure comics artist Milton Caniff. Caniff's "realistic effects", which "brought comics closer to the language of film", "created the formula for American comics" henceforth (García 2015 [2010]: 67-68).

In practice, manga from Japan exhibits a diverse range of formal features and genres, having come into existence partly through the influence of "North American comics" in the 1920s (García 2015 [2010]: 32; see also Schodt 1983: 38-54). Nevertheless, in The Vanished Path, Murthy appears to borrow, as I will demonstrate shortly, certain aesthetic techniques in manga that he identifies as typical of the medium in "A Form of Writing" (2011). In my forthcoming analyses of certain panels in The Vanished Path, I will show that Murthy effects his secular agenda by asking the reader to be attentive to the technique, in particular "the cumulative effect of the entire page" (2011: no page). Murthy's panels appear to exemplify a tempo-spatial configuration whereby the reader is required to be skilled at scanning the "entire page at once" in order to absorb information that may seem tangential to the main narrative of the protagonists' travels, but actually turns out to be important for triggering an interrogation of the status quo of religious politics. Murthy shows rather than tells his readers the socio-political benefits of being secular; he plants hints through the breadth of the "entire page" to offer a cautionary tale about the potentially catastrophic consequences of socially divisive religious conflict (ibid.). In analysing the visual text in individual panels, therefore, I will draw upon news and current affairs reports as well as relevant critical perspectives from comparative religious studies and South Asian studies. A point to note here, however, is that in view of Murthy's explicitly stated debt to Japanese manga, all subsequent references to manga in this article will allude to manga produced in Japan and not elsewhere. I state this as a cautionary note in light of Casey Brienza's "Introduction" to Global Manga (2015), where she has argued convincingly for the identity of manga as a global cultural medium today, often having little or nothing to do with the Japanese origins of the medium although created through processes of transnational traffic.

In demonstrating Murthy's creative appropriation of the tempo-spatial configuration often found in Japanese manga, an auxiliary aim of this article is to situate The Vanished Path in an alternate cultural nexus from those previously invoked in both creative and critical engagements with comics and graphic novels in India. Murthy's turn towards manga techniques can be interpreted as aesthetically idiosyncratic, I would suggest, when contextualised against the history of comics readership and the socio-economic backdrop of the comics industry in India. In another essay entitled "An Art Without a Tradition: A Survey of Indian Comics" (2009), Murthy noted the popularity of the vigilante heroes Tarzan, Phantom and Mandrake in American adventure comics from 
the 1920s and 1930s in India, and the adaptation of such figures in indigenous Indian comics of the 1960s-70s (García 2015 [2010]: 65-67; see also Mathur 2010: 175186). The militiaman "Bahadur", with a name meaning "brave" in Hindi, provides an instance of such adaptation (Pathak 1989: 534).

In light of the fact that India used to be a former major colony of the British Empire - a fact, which has fostered an abiding cultural proximity to the Anglo-American world - Indian comics artists and graphic novelists have, by and large, looked towards Western rather than East Asian models. The bulk of cultural activity in this field, as Murthy has pointed out, has been weighted towards American comics traditions and, by extension, the West, rather than other parts of Asia. A similar geopolitical impetus is borne out in scholarship on Indian comics as well as graphic novels, which includes, currently, a sizeable body of both full-length and shorter studies, including Pramod K. Nayar's recent The Indian Graphic Novel (2016; see also Chandra 2008; Mathur 2010; McLain 2009; Srinivas 2010). While Nayar makes a persuasive case for "the Indian graphic narrative as increasingly central to the canon of Indian Writing in English" (2016: 4-5, 7, 31), comics artists or graphic novelists outside India on whom he grounds his study, including Scott McCloud, Art Spiegelman, and Frank Miller, all happen to be American. To elaborate, Nayar's study discusses, for instance, the graphic novel Bhimayana (Natarajan et al. 2011), based on the life of the statesman Dr. B.R. Ambedkar, who also features as a public figure in The Vanished Path for his combating of the social discrimination created through the hierarchical Hindu caste system (Murthy 2015a: 50). Nayar locates influences for the "non-realist representation" of "history" in Bhimayana in Art Spiegelman's Maus (Nayar 2016: 190-191), apart from the folk art of the Gond community in central India $(135,140)$.

In contrast, the present article maps out a different psycho-geographic terrain by pointing to Murthy's transformation of manga techniques from Japan to India, working through an investigative framework which takes a hint from Jaqueline Berndt and Bettina Kümmerling-Meibauer's “Introduction” to Manga's Cultural Crossroads (2013). As Berndt and Kümmerling-Meibauer have noted, manga produced everywhere today is shaped by "transcultural flows" inevitable in the dynamics of "globalization" (2013: 3). In charting the "flows" newly enabled by the fine-spun contemporary crosscultural traffic between two different Asian cultures rather than the West and India, this article aims to update the critical topography on Indian comics and graphic novels, demonstrating the creative impact of freshly emergent pathways of cultural globalisation. Indeed, a critical recognition of this alternate pathway of intercultural traffic is procedurally overdue, in view of the presently shifting readership patterns of comics and graphic novels in India. One may note, for instance, that The Vanished Path has been brought out by the globally known publishing firm HarperCollins, and large publishing companies do tend to target particular market segments so that the books they release might prove profitable. In an author interview, Murthy has pointed to the increasing "popularity" of manga among young adults and teenagers "especially from urban middle-class" backgrounds (quoted in: Dundoo 2015). The "popularity" of 
manga may owe to the fact that these young readers have opportunities to read, discuss or draw and exhibit their own work on fan communities such as dedicated Facebook groups (e.g. "Manga India", "Manga Planet India"). They may also view television shows in the related medium of anime on the multinational network Animax. These young readers may well comprise the market segment targeted by the publisher of The Vanished Path, and they are most likely equipped with the skills of reading the "entire page at once", as Murthy's visual text might desire them to do (Murthy 2011: no page).

An illustrative instance in The Vanished Path of information about religious politics dispersed through the "entire page" can be found in the protagonists' visit to a café at the town of Kushinagar, which spawns a conversational exchange, ostensibly pleasant in spirit (Fig. 2). The café owner, T.K. Roy, introduces the figure of Nandratna Bhikku, another of his guests, to the protagonists (Murthy 2015a: 53). This Bhikku, a Buddhist monk, happens to be a man of letters (cf. de Bary 1969). He edits a Hindi newspaper called Buddha Jyoti, the word "jyoti" meaning 'a flood of light' or 'lustre' in Hindi (Pathak 1989: 277).

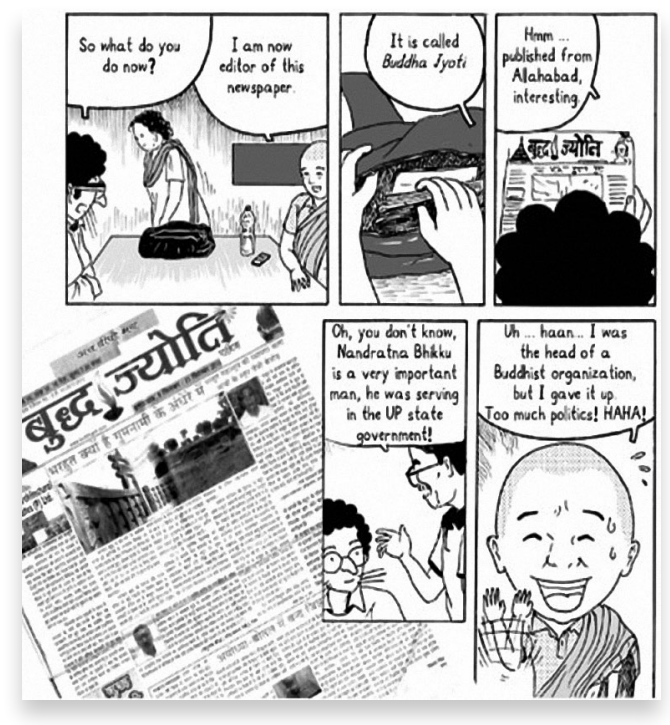

Fig. 2. T.K. Roy introduces the Buddhist monk Nandratna Bhikku SI. 2. T. K. Roy predstavlja budističkoga redovnika Nandratnu Bhikkua

The leading article here in the newspaper issue that Nandratna Bhikku offers is about Buddhist ruins and relics at a place called Bharhut in central India. The headline at the bottom of the newspaper, however, states "Ayodhya - the genie in the bottle". The Hindi text in the headline is just about decipherable: one cannot guess at the contents of the article. However, "Ayodhya", the name of a town in northern India, works as leitmotif within The Vanished Path, being invoked a number of times through Alka and Bharath's niggling anxiety about the "verdict" surrounding the "Ayodhya dispute". The 
protagonists track news and current affairs from time to time, and even in Nepal they are keen to ascertain that there has been no violence following the "verdict" in Ayodhya (Murthy 2015a: 2, 104).

The "Ayodhya dispute" refers to cataclysmic events in the year 1992, when the town attained the dubious distinction of having become a political hot spot. Traditionally, Ayodhya has been known as the mythological birthplace of Lord Rama, the protagonist of the ancient Indian epic The Ramayana. In 1992, the centuries-old Islamic Mughal mosque, the Babri Masjid, was demolished by Hindu hard-liners, acting on claims that there had been a Hindu temple commemorating the exact birthplace of Lord Rama where the Islamic mosque then stood. Following the demolition of the mosque, religious riots gripped the Indian subcontinent, leaving more than two thousand people dead. The event marked a turning point in the rise of Hindu nationalism, rending apart the relatively secular fabric of the nation, governed federally by the political party called the Congress (I) at the time (cf. Mander 2015: 216, 219).

The Congress (I) - previously named the Indian National Congress - has been long associated, according to a number of scholars, with enshrining secular ideologies in constructs of India as a modern nation-state. Jona Aravind Dohrmann (2005) has, for instance, historicised the secular tradition within the Indian National Congress, given the party's distinctive identity as a self-avowedly pan-Indian organisation accommodating members of all religious faiths and political persuasions. This pluralistic identity was key to the spearheading role played by the Indian National Congress in the struggle against British colonialism preceding Indian Independence in 1947. Under the auspices of the pre-eminent Congress leaders, Mahatma Gandhi and Jawaharlal Nehru, secular and democratic values were implemented in the Indian Constitution, which came into force in 1950, shortly after Independence from British rule in 1947.

The modern Indian understanding of secularism has been illumined further by scholar C.S. Adcock (2013) in his reading of the Gandhian tradition of "tolerance", predicated upon ideals of religious pluralism. These ideals, according to Adcock, were correspondingly translated into the political and legal arena. For instance, in response to violent clashes between Hindu and Muslim inhabitants in the northern Indian city of Kanpur in 1931, the Indian National Congress prepared a "Kanpur Report" which became foundational to the discourse of secularism within the anti-colonial struggle. In Figure 2, The Vanished Path appears to hark nostalgically back to the relatively stable foundation of secularism in the post-Independence era, nurtured by the Congress and undone by Hindu nationalists. Young readers of manga in India may not know or remember the traumatic events of 1992 precisely (Murthy 2011: no page). Indeed, the newspaper headline in Figure 2 appears to cite phenomena not related to issues of direct relevance to practising Buddhists in contemporary India; the Hindu nationalists' ire has been targeted largely at the significantly large Muslim minority population, as discussed above, rather than the (far smaller) Buddhist minority (Population 2011). Yet, Murthy, trusting to the young readers' skill at scanning the "entire page," directs their attention to "Ayodhya" through the newspaper headline, pointedly arousing curiosity 
about the legal disputes that arose from the religious conflicts in 1992 and continue to plague the protagonists' travels in 2010. The visual text thus encourages readers to question emergent socio-political narratives of a supposedly singular and seamless Hindu nation.

Lest such readers should dismiss the aftermath of the "Ayodhya dispute" as past history, irrelevant to the present, Murthy supplies a timely corrective in Figure 3. In the foreground, Alka proposes renting overnight accommodation at a lodge called Pathik Niwas, and Bharath leans to rest against a roadside wall plastered over with a poster, as revealed by the background (Murthy 2015a: 46).

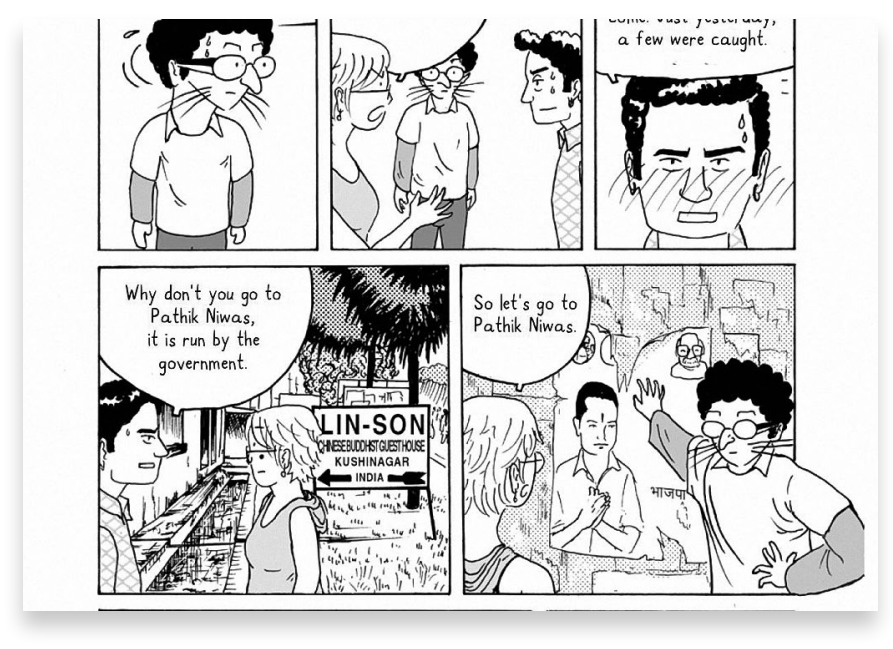

Fig. 3. Alka suggests a place for an overnight stay

SI. 3. Alka predlaže mjesto gdje mogu prenoćiti

The poster seems to be there almost as an afterthought, yet a reader familiar with the contemporary Indian political landscape would recognise the benignly smiling face of the public figure L.K. Advani, positioned at the top left of Bharath's head. Advani is well known as the political leader who captained the Hindu hard-line movement in the "Ayodhya dispute" (Mander 2015: 217). Advani's face floats ominously above that of Bharath's, echoing the omnipresent visage of Big Brother, which George Orwell deployed as a metonym for mass surveillance in his critique of totalitarian regimes in his dystopian novel Nineteen Eighty-Four (1949). The Hindi text below states the name of Advani's political party, the Bharatiya Janata Party (shown on the poster in the abbreviated form "BJP"). The momentariness of this image can be gauged by appreciating that the BJP is the political party at the helm of State governance in India today. Since the party's ideology and practices bear palpable continuity with the Hindu nationalism that fuelled the demolition of the mosque at Ayodhya, as discussed above, Bharath may in reality be less free in his religious choices than his relaxed body language appears to indicate (cf. Doniger \& Nussbaum 2015). 
Given the manifest swell of Hindu nationalism in the Indian socio-political fabric, Bharath and Alka appear to feel ambushed all the time by flippant displays of Hindu majoritarian sentiment, given their status as parvenu Buddhists not yet securely ensconced in their new religious identities. Signs of Hindu religious dominance inhabit the streets and commercial establishments that the protagonists visit (Fig. 4).

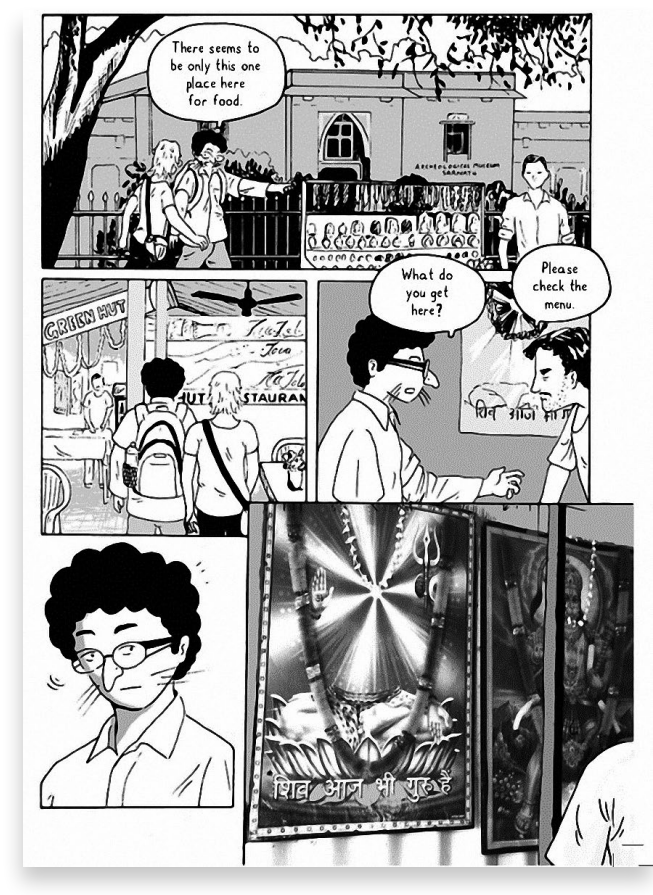

Fig. 4. The protagonists enter a restaurant

SI. 4. Protagonisti ulaze u restoran

In Figure 4, Bharath is interested mainly in what kind of food one can get at the disingenuously named Restaurant Green Hut, a humble establishment which features an apparently inconspicuous menu. Yet, Bharath's attention is drawn inadvertently towards the posters on the wall, dedicated to the Hindu gods Shiva and Hanuman. Drawn in an overblown visual style typical of Indian calendar art, the Hindi text on one of the posters proclaims that "Lord Shiva" is the all-encompassing "guru even today" in a tone of brassy self-assurance (Murthy 2015a: 21; cf. Jain 2007). Bharath's glance at the poster is incidental to the main subject of the culinary offerings at the Green Hut. Yet, his expression, comprising a telling mixture of scepticism and astonishment, alerts the reader to the absurdity of the messianic posture enmeshed here within a seemingly self-evident norm of Hindu belief. Bharath occupies a position of alterity which happens to be Buddhist, but the position would apply equally to any reader not invested in the belief system propounded by the poster. 
Simultaneously, The Vanished Path points out acts of subtle coercion in a social environment predicated upon Hindu normativity. Time and again, the protagonists are offered Prasad, that is, food that is supposed to be deified through rituals of Hindu worship, by priests who will not take no for an answer (cf. Pathak 1989: 502). On occasions when Bharath and Alka visit Buddhist sites, they find Hindu shrines and temples encroaching upon these spaces. A characteristic instance can be seen in Figure 5. Here, the protagonists visit Bodhgaya, where the Buddha is supposed to have gained Enlightenment within the span of a pristine moment, and is thus located at the heart of Buddhist sacred topography (Murthy 2015a: 211; see also Murthy 2015a: 109, 113, 115, 117-118, 162; cf. Lopez, Jr. 2002: 178).

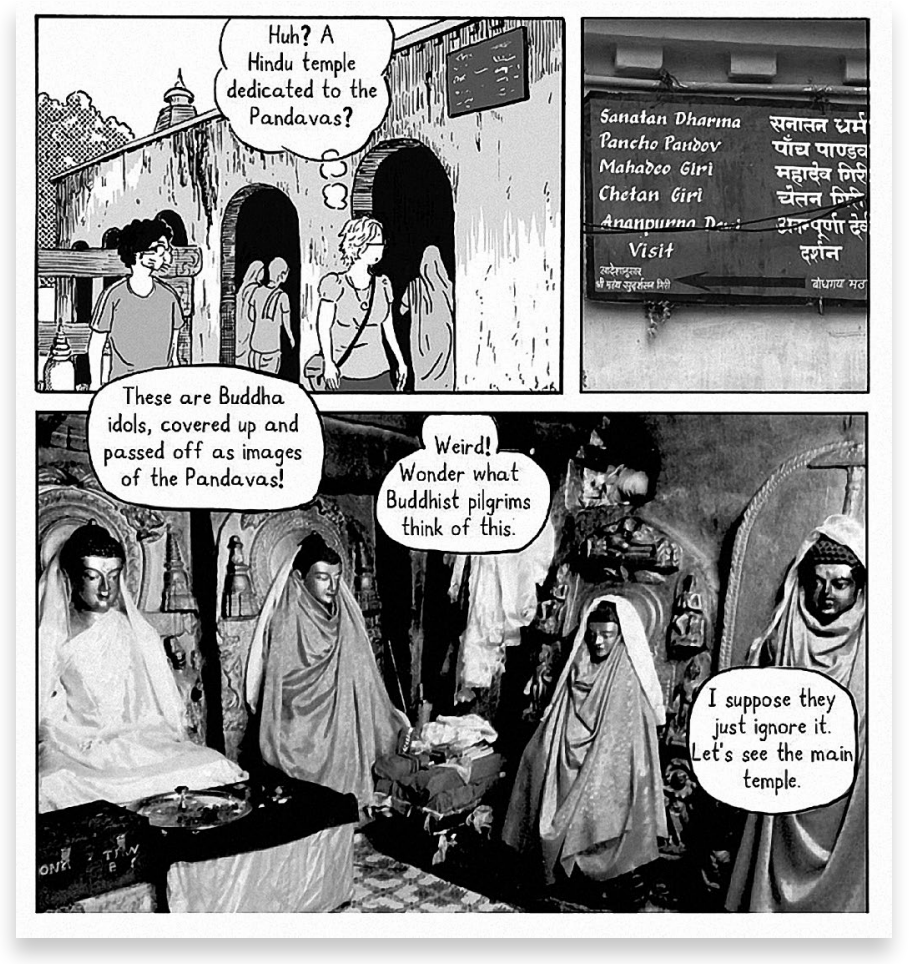

Fig. 5. Bharath and Alka at Bodhgaya

Sl. 5. Bharath i Alka u Bodhgayi

Even at this epicentre of Buddhist faith the protagonists find, as Alka says, "a Hindu temple" where statues of the Buddha are being "passed off" as those of the Pandava brothers, mythical heroes of the other major epic from ancient India, The Mahabharata. The photograph of the Buddha statues is interpreted for the reader through speech bubbles spilling over from the panel above, expressing the protagonists' consternation and some rumination about what "Buddhist pilgrims" must "think of" this pesky 
appropriation of the Buddha (Murthy 2015a: 211). Given the historically documented co-existence of common wellsprings of Buddhist and Hindu belief systems in early Indian culture, one might make a case that the protagonists should not feel so affronted by this repurposing of the Buddha statues and simply view these statues as expressions of religious syncretism. Romila Thapar's discussion, for instance, has located historical precedent for the appropriation or incorporation of Buddhist beliefs within the Hindu sect of Vaishnavism, with the Buddha having been recognised as one of the ten incarnations of the sect's chief deity Lord Vishnu (1989: 220). Examined against the recent upsurge of Hindu nationalism, however, the protagonists have reasons to feel insecure at the representation of the Buddha in the shape of the "Pandavas". A key portion of The Mahabharata comprises the treatise The Bhagvad Gita, now commonly characterised as the holy book of the Hindus. Originally, The Bhagvad Gita was structured as a conversation between the Pandava warrior Arjuna and his charioteer Lord Krishna, embedding complex enquiries on the nature of ethics (cf. Sen 2005: 3-4). With the help of historical evidence stretching back to the first millennium AD, Thapar has illumined the mechanisms of authority that have led to The Bhagvad Gita being "regarded as sacred" for Hindus (1989: 211). Thapar argues that such an identification resulted from retrospective nineteenth-century European Orientalist processes of reading Hinduism as a religion analogous to the Semitic religions of Christianity and Islam, centred on a single "revealed book" (ibid.) such as the Bible or the Koran (Thapar 1989: 218, 228-229). Such readings of Hinduism appear to have animated the Hindu nationalists' frequent demand that the Bhagvad Gita become compulsory reading in primary and secondary schools in India, without respect for students' own religious affinities (or lack thereof) (Bhardwaj 2015; Declare Gita 2015). Given such tangible socio-political commandeering of a key part of The Mahabharata, the protagonists of The Vanished Path naturally do not appear to feel sanguine about the intrusion of Hindu symbolism into Buddhist sacral space.

Furthermore, the protagonists are perpetually confronted with the undeniable fact of the historical disappearance of Buddhism "by the end of the thirteenth century", despite the coterminous existence of the religion's intellectual traditions with those of "brahminical" Hinduism (Murthy 2015a: 42, 170). Given that certain sources ascribe Buddhism's disappearance from India to documented episodes of religious persecution, the protagonists have good reason to be concerned lest history should repeat itself. An instance of the banishment of Buddhist belief owing to persecution is shown in Figure 6. Here, the protagonists have been visiting the ruins of Nalanda, the sprawling Buddhist centre of learning at the height of its fame towards the first millennium AD (170175). As scholar of comparative religion Donald Lopez, Jr. has elucidated, the centre comprised a monastery that "housed ten thousand monks" and nurtured pioneering traditions of regular cultural exchange with Chinese and Tibetan scholars and travellers (2002: 169, 171-172). On the panel preceding Figure 6, Bharath has been discussing "Xuanzang, the best known of Chinese Buddhist travellers", who lived in Nalanda "for two years", "translating Sanskrit Buddhist texts" (Murthy 2015a: 174). 


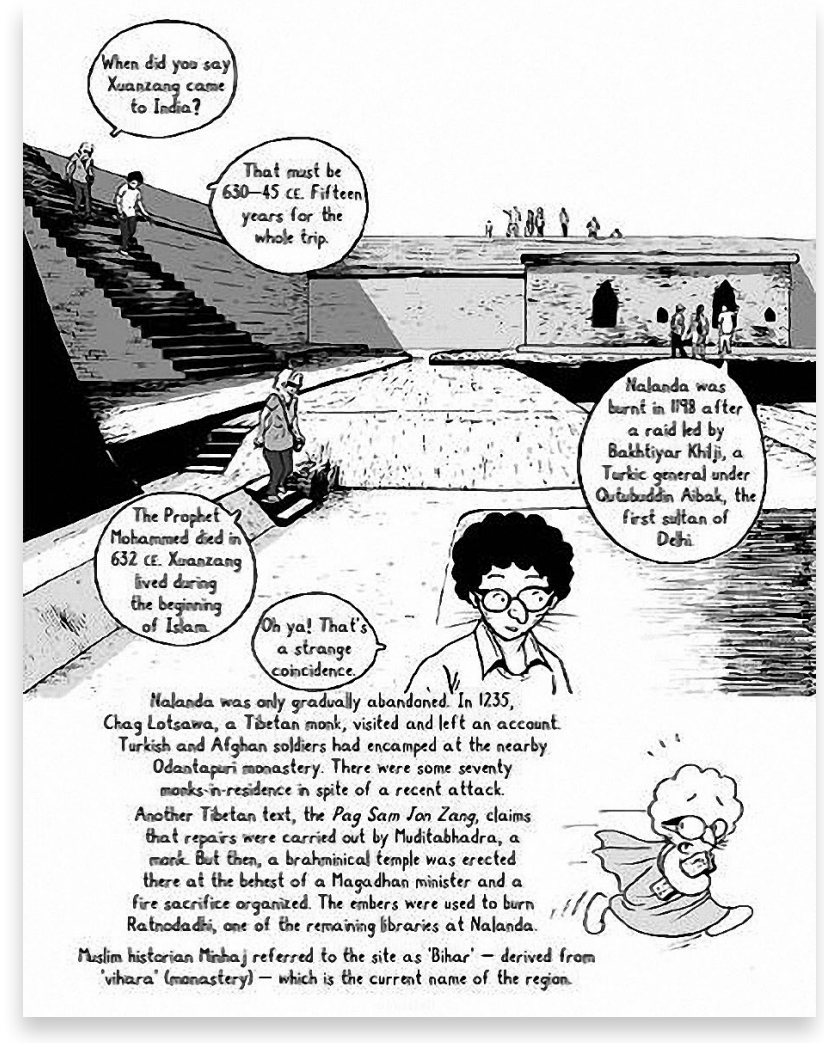

Fig. 6. Bharath and Alka at the ruins of Nalanda

Sl. 6. Bharath i Alka na ruševinama Nalande

In Figure 6, Alka and Bharath continue their conversation about Xuanzang in a visual arena that shows Alka walking down separate and successive flights of steps on a page wholly covered by a single panel. The reader's gaze is directed towards Alka's physical progress, as Murthy's drawing generates a sense of ongoing movement through the "2-dimensional" arrangement of "space", which he mentions as a characteristic typical of manga in his essay "A Form of Writing" (2011: no page). This sense of movement is augmented by the presence of a speech balloon to the right, presumably spoken by a tourist guide explaining the reasons for the abandonment of Nalanda to other visitors. The guide says that Nalanda was "burnt" down in 1198 AD after "a raid led by Bakhtiyar Khilji, a Turkic general under Qutubuddin Aibak, the first sultan of Delhi" (Murthy 2015a: 175). However, if the reader glances at the monologue towards the bottom of the panel, the guide's attribution of the destruction of Nalanda to Islamic sources does not appear to be the final word. The monologue attributes equal agency for the demolishment of the institution of Nalanda to the erecting of a "brahminical temple" at the site, which delivered the deathblow via a "fire sacrifice" that burnt down a major library (ibid.). Murthy thus stops short of pointing fingers at foreign "Turkic" 
Islamic invaders alone for the systematic eclipse of Buddhism from India - in contrast to Hindu nationalist narratives - and instead presents the home-grown Brahminical "Magadhan minister" as equally culpable (ibid.; cf. Thapar 1989: 226-227).

Indeed, Murthy's assigning of causes for the disappearance of Buddhism to diverse religious sources is an accurate reflection of positions articulated in recent scholarship on the subject. Lopez, Jr., for example, states that although Muslim invasions from the eleventh century onwards have been commonly accepted as the historic reason for Buddhism's disappearance, the phenomenon may be linked to other factors too, such as the diminishing of "royal patronage" and the assimilation of "Buddhist practices" into Hinduism (2002: 169). Murthy, similarly, in letting the tale be told by multiple tellers in his visual text, destabilises any authoritative narrative about Islam's eradication of Buddhism. Moreover, Murthy presents these multiple narratives about Buddhism's disappearance from India with a sense of objective distance rather than elegiac, subjective emotion. The feeling of sic transit gloria mundi is transposed onto the comical figure of the persecuted bhikku placed bottom right, who appears to be running away from scenes of destruction with scriptural scrolls tucked under his arm. This cartoonesque, impish bhikku well be the speaker of the monologue in Figure 6, since he also punctuates the narrative of The Vanished Path in the role of storyteller in episodes elsewhere (Murthy 2015a: 6, 11, 20, 37; cf. Murthy 2011). The glasses, unruly curls and exaggerated whiskers of the bhikku appear to make him an alter ego of Bharath in caricature, perhaps echoing the figure of the chibi in manga, which Murthy has flagged in "A Form of Writing" as the recurrent, codified character of a "small person/ short child" which signifies "distorted versions of characters" representing "certain emotions" (2011: no page). In the case of the bhikku, the distancing of "emotions" through humour perhaps lends a touch of fallible humanity to the protagonists' solemn search for personal moorings in their religious faith, even as Murthy toys with his own critical understanding of the characteristic features of manga.

Through his oxymoronic representation of the funny yet angst-ridden bhikku, Murthy avoids any easy identification of martyrdom with the practice of the Buddhist faith. Even as Bharath and Alka regret the multiple erasures of the early Buddhist tradition in India, affirming their personal loyalty to Buddhist precepts, they are also sorely disturbed by a degenerate commercialism associated with certain modern expressions of Buddhism. As Figure 7 shows, the protagonists have a significant encounter with these practices in and around the former Buddhist monastery of Jetavana and the neighbouring ancient city of Shravasti, where most liturgical activity appears to be performed by overseas pilgrims who bring in sacramental funds to Indian sites. This phenomenon evinces a historical reversal of the original outflow of Buddhism from northern India and Nepal to other parts of Asia, and the subsequent splitting of the faith into two main branches. These branches include the "Southern Buddhism" of "Sri Lanka, Thailand, Cambodia, Burma, Laos, and parts of Vietnam", and "Northern Buddhism", which refers to Buddhism practised in "China, Japan, Korea, Tibet, and Mongolia” (Lopez, Jr. 2002: 169-170). 


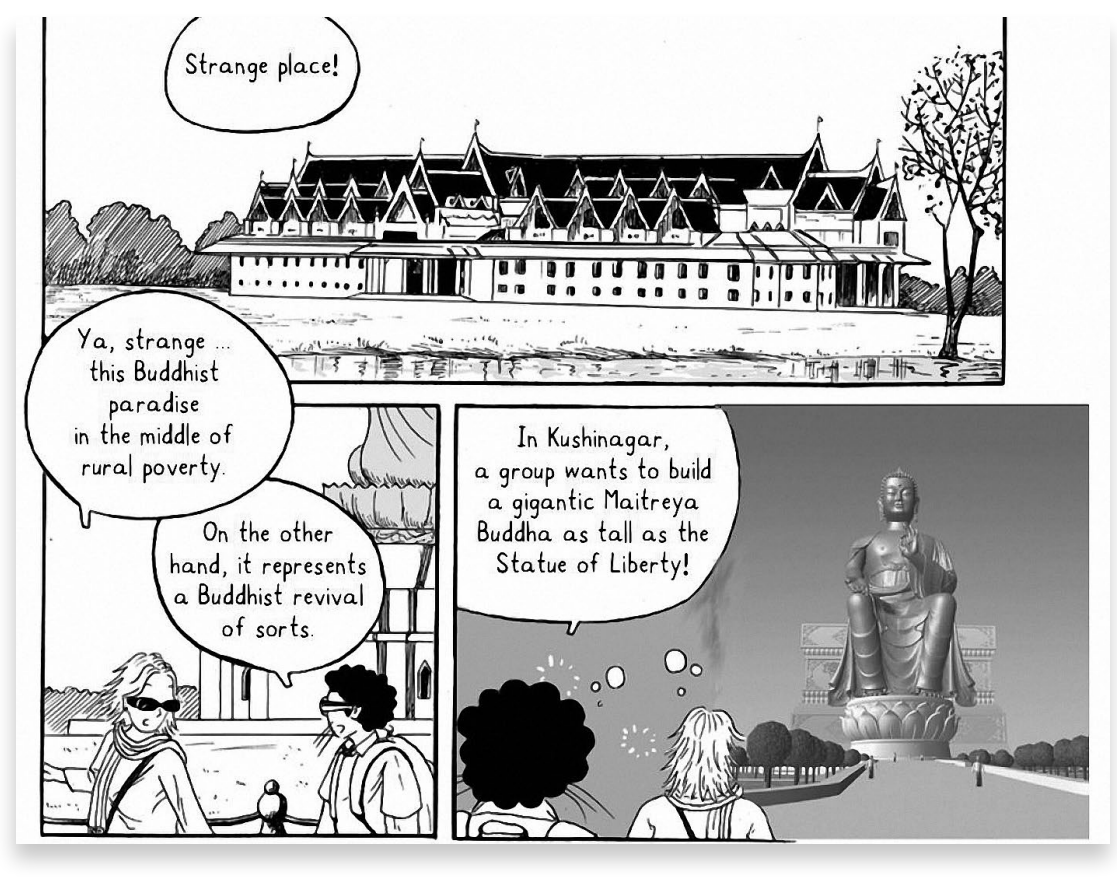

Fig. 7. Bharath and Alka visit the Mahamongkol temple Sl. 7. Bharath i Alka obilaze hram Mahamongkol

Both "Northern" and "Southern" Buddhism appear to be represented in the site that the protagonists visit. In an article and an interview, Murthy has observed that "the Buddhist pilgrimage route" has displayed a steep upturn in the number of pilgrims from China, which coincides with the country's growing economic prosperity over the last two decades, "particularly in the affluent classes" (Dundoo 2015; Murthy 2015b). In Figure 7, the protagonists are astounded by a massive statue of the Buddha at the humongous "Mahamongkol" temple run by a Thai organisation (Murthy 2015a: 149-151). Alka's social consciousness prompts her to ruminate sadly on this "paradise in the middle of rural poverty" (151) in a speech balloon sutured to the previous panel as a comment on the temple. Her observation is foreshadowed in the pages preceding these panels, where Murthy points out that children living in the area struggle for access to even primary school education. Alka chitchats with a local rickshawallah, and on seeing some children playing on the street in the daytime, she wonders aloud whether the children have the opportunity to go to school. The rickshawallah responds that there is a "government school" in the area "which gets flooded every monsoon", and is hence "closed most of the time" (139). In Figure 7 above, Alka is thus sharply aware of the social problems that may ensue through the creation of a rich/poor divide in the area. Her observation receives silent assent from Bharath, even as he reluctantly admits that new sacral edifices such as the Mahamongkol temple represent "a Buddhist revival of sorts" (151) in India. Certainly, the ostentatiousness of such new edifices militates 


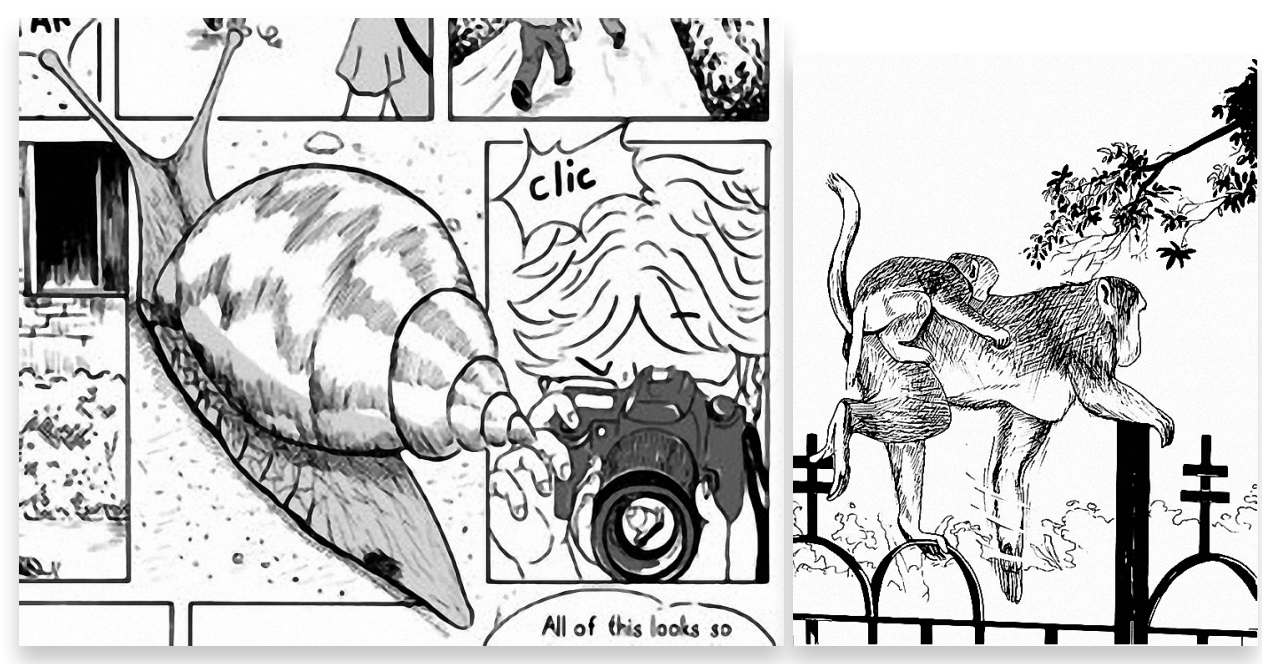

Figs. 8. \& 9. Close-ups of animals

Sl. 8. i 9. Životinje izbliza

against the originally egalitarian, anti-caste impulses in early Buddhism, as outlined by Osamu Tezuka. The protagonists' joint scepticism towards such tinsel leads them to conjure a joint nightmare vision of a proposed statue of the Buddha "as tall as the Statue of Liberty" in Kushinagar (ibid.). The panel presents a collage of two images, fusing the apparently documented reality of a photograph with the statue of the Buddha imagined within the protagonists' thought bubbles. The protagonists' exclamation of bemusement conveys to the reader that the protagonists, despite their religious affiliation with Buddhism, remain eminently capable of critiquing excesses associated with the religion. Ultimately, The Vanished Path does not evangelise on behalf of Buddhism as a perfect religion.

No religion can provide political resolution, as the visual text of The Vanished Path appears to imply. The only realms of history that remain pristine, and untouched by religious conflict and caste differentiation, seem to lie outside the human world. The text is interspersed with a series of pictorially dazzling close-ups of silent insects, birds, and animals, as depicted in Figures 8 and 9 (Murthy 2015a: 88, 121; see also Murthy 2015: 100, 108-109, 115, 123, 131; cf. Khanna 2015).

These images may derive from Buddhism's reputation for an animal-friendly religion. The Edicts of the Buddhist Emperor Ashoka, of the Mauryan dynasty (ca. 304BC-232BC), for instance, engraved and still visible on stone pillars and caves in many parts of the Indian subcontinent, made much of the provisions for animal welfare during his reign (The Edicts 1993). Within The Vanished Path, the wordless, lingering images of terrestrial and arboreal life (Figs. 8 and 9) appear to segue logically to Figure 10 in full colour on the flyleaf at the back of the text. Here, the protagonists stand at the ruins of Kapilavastu, where the Buddha is reputed to have spent the early years of 
his life. The image is presented in soothing monochromes of green and brown, and reproduces a black-and-white image featured earlier in the text (Murthy 2015a: 106, flyleaf).

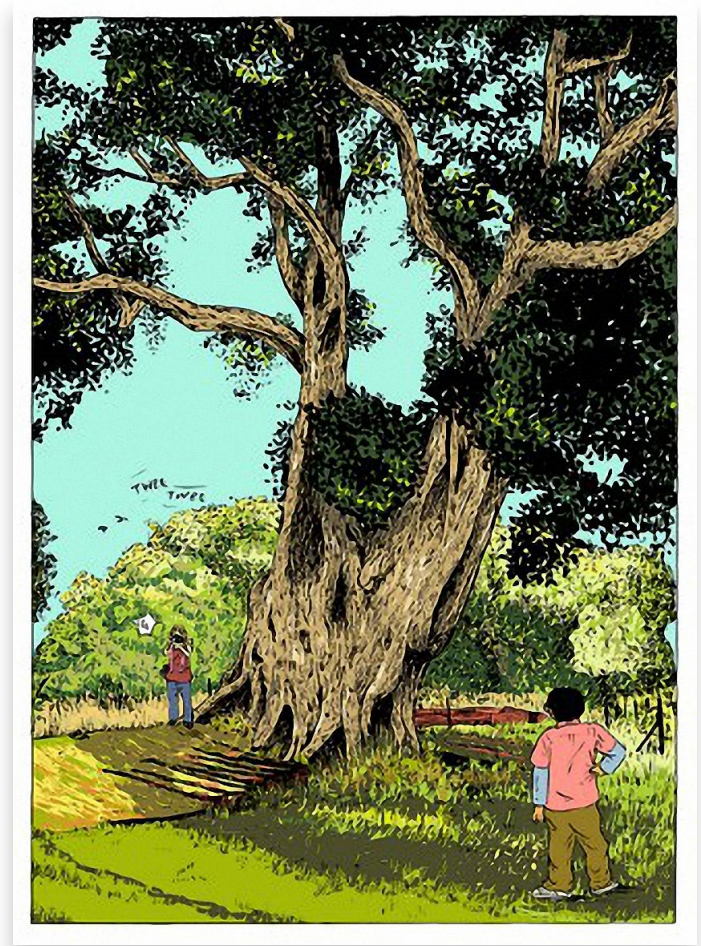

Fig. 10. Bharath and Alka at the ruins of Kapilavastu

Sl. 10. Bharath i Alka na ruševinama Kapilavastua

Only two sounds appear to interrupt this symphony of silence: the onomatopoeic words representing the clicking camera ("Clic") and the parrots ("Twee twee") flying into aerial horizons. Perhaps this largely silent image, enwrapped in serenity, exemplifies the doctrine of "ahims $\bar{a}$ or non-violence" towards others, which was, according to Thapar, "foundational to [the] teaching" of Buddhists and Jains but also shared with Hinduism, even "Brahmanism" (1989: 218). If so, Murthy's aesthetic of showing rather than telling reaches an apogee in demonstrating the socio-cultural value of being open to religions and belief systems other than one's own, and, concomitantly, welcoming multiple and dissonant narratives about the nation-state.

While The Vanished Path, therefore, is a personal journey into the historical roots of Buddhism, the text simultaneously advocates secular values in a multi-religious society, and is grounded in a position of rational scepticism towards certain forms and functions of organised religion, as the discussion of Figure 7 shows. Murthy's position may owe to a precedent set by Ambedkar; as sociologist Gail Omvedt has argued, 
Ambedkar took up "a kind of modernistic Enlightenment version" of the Buddhist scriptural code of the "Dhamma" (2003: 8). Having earned doctorates in economics at both Columbia University and the London School of Economics, Ambedkar was well acquainted with the methodologies associated with European philosophy and political thought, including the empiricist approach of the Enlightenment tradition and the intellectual legacies of sceptical enquiry (Bhimrao Ambedkar 2004; Hoagwood 1988: 4-5). Likewise, Murthy appears to encourage young readers to continually enquire sceptically into the contents of the "entire page" in The Vanished Path. His strategic positioning of visual text works with a tempo-spatial configuration in which his choice of medium turns out to be the message: the graphic travelogue (in contrast to the more well-established convention of prose) enables his secular plea. Simultaneously, Murthy alerts the reader that the religious conflicts of long ago may continue to shape the here and now.

\section{Notes}

All translations from the portions of the text in Hindi in The Vanished Path are my own. I am deeply obliged to Bharath Murthy for providing the images in this paper and for access to unpublished draft material (some of which has been posted on his blog or published elsewhere later), and for elucidating many aspects of his work through email interviews.

Some sections of this article (particularly the introductory parts on the cultural implications of Murthy's artistic alignment with Japanese manga) of necessity intersect with another article of mine under preparation, which highlights the multilingual literacies involved in reading The Vanished Path. Acknowledgements due have been made in the other article.

\section{References}

Adcock, C.S. 2013. The Limits of Tolerance: Indian Secularism and the Politics of Religious Freedom. New York: Oxford University Press. <www.oxfordscholarship. com> (accessed 25 April 2016).

Anderson, Benedict. 1983. Imagined Communities: Reflections on the Origin and Spread of Nationalism. London: Verso.

Berndt, Jaqueline \& Bettina Kümmerling-Meibauer. 2013. Introduction. In Manga's Cultural Crossroads, eds. Jaqueline Berndt and Bettina Kümmerling-Meibauer, 1-15. New York \& London: Routledge.

Bhardwaj, Mukesh. 2015. Bhagavad Gita a part of school curriculum. Indian Express. $<$ http://indianexpress.com/article/india/india-others/haryana-govt-pushes-to-makebhagavad-gita-part-of-school-curriculum/> (accessed 1 August 2016).

Bhimrao Ambedkar. 2004. C250 Celebrates Columbians Ahead of Their Time. $<$ http://c250. columbia.edu/c250_celebrates/remarkable_columbians/bhimrao_ambedkar.html> (accessed 12 December 2016).

Brienza, Casey. 2015. Introduction. In Global Manga: “Japanese” Comics Without Japan?, ed. Casey Brienza, 1-15. New York \& London: Routledge.

Chandra, Nandini. 2008. The Classic Popular: Amar Chitra Katha, 1967-2007. New Delhi: Yoda. 
Daniyal, Shoaib. 2015. How Narendra Modi Helped Spread Anti-Beef Hysteria. Scroll.in. $<$ http://scroll.in/article/760006/how-narendra-modi-helped-spread-anti-beefhysteria $>$ (accessed 1 August 2016).

Daniyal, Shoaib. 2016. Hindutva Hypocrisy: Why is Beef Banned as Food but Bull Torture Allowed for Sport? Scroll.in. <http://scroll.in/article/801557/hindutva-hypocrisyhow-is-beef-as-food-banned-but-bull-torture-for-sport-allowed $>$ (accessed 1 August 2016).

de Bary, William Theodore. 1969. Early Buddhism. The Buddhist Tradition in India, China and Japan, ed. William Theodore de Bary, 3-54. New York: Vintage.

Declare Gita as National Book, demand BJP members led by Yogi Adityanath. 2015. First Post India. <http://www.firstpost.com/india/declare-gita-as-national-book-demandbjp-members-led-by-yogi-adityanath-2555816.html > (accessed 1 August 2016).

Desai, Prajna. 2015. The Middle Way without Middlemen: A Review of Bharath Murthy's The Vanished Path. The Caravan. <http:/www.caravanmagazine.in/vantage/reviewbharath-murthy-vanished-path $>$ (accessed 29 May 2015).

Dohrmann, Jona Aravind. 2005. The Congress Party as the Creator, Preserver and Destroyer of the Indian State? In Indien 2005. Politik, Wirtschaft, Gesellschaft, ed. Werner Draguhn, 53-77. Hamburg: Institut für Asienkunde.

Doniger, Wendy and Martha C. Nussbaum. 2015. Introduction. In Pluralism and Democracy in India: Debating the Hindu Right, eds. Wendy Doniger and Martha C. Nussbaum, 2-22. Oxford: Oxford University Press. <oxfordscholarship.com> (accessed 25 April 2016).

Dundoo, Sangeetha Devi. 2015. Sketches, Notes and a Story. The Hindu. <http://www. thehindu.com/features/metroplus/sketches-notes-and-a-story/article7188336.ece. $>$ (accessed 26 May 2015).

García, Santiago. 2015 [2010]. On the Graphic Novel. Trans. Bruce Campbell. Jackson, Mississippi: University Press of Mississippi.

Hoagwood, Terence A. 1988. Skepticism and Ideology: Shelley's Political Prose and Its Philosophical Context from Bacon to Marx. Iowa City: University of Iowa Press.

Ilaiah, Kancha. 2015. Beef Ban is an Attempt to Impose Upper-Caste Culture on Other Hindus. Scroll.in. <http://scroll.in/article/714661/beef-ban-is-an-attempt-to-imposeupper-caste-culture-on-other-hindus-kancha-ilaiah> (accessed 1 August 2016).

Jain, Kajri. 2007. Gods in the Bazaar: The Economies of Indian Calendar Art. Durham: Duke University Press.

Khanna, Rakesh. 2015. A Self-Effacing Scrapbook of Buddhist Ruins. The Asian Age. $<$ http://www.deccanchronicle.com/150527/lifestyle-booksart/article/book-reviewvanished-path-graphic-travelogue-self-effacing $>$ (accessed 3 June 2015).

Lopez, Jr., Donald S. 2002. Introduction: Buddhism. In Religions of Asia in Practice: An Anthology, ed. Donald S. Lopez, Jr., 165-196. Princeton \& Woodstock: Princeton University Press.

Mander, Harsh. 2015. Looking Away: Inequality, Prejudice and Indifference in New India. New Delhi: Speaking Tiger.

Mathur, Suchitra. 2010. From Capes to Snakes: The Indianization of the American Superhero. In Comics as a Nexus of Cultures: Essays on the Interplay of Media, Disciplines and International Perspectives, eds. Mark Beringer, Jochen Ecke and Gideon Haberkorn, 175-186. Jefferson, NC: McFarland.

McLain, Karline. 2009. India's Immortal Comic Books: Gods, Kings, and Other Heroes. Bloomington: Indiana University Press.

Murthy, Bharath. 2009. An Art Without a Tradition: A Survey of Indian Comics. Marg: A Magazine of the Arts 61 (2): 38-53. 
Murthy, Bharath. 2011. A Form of Writing: An Essay on the Comic. Unpublished draft.

Murthy, Bharath. 2015a. The Vanished Path: A Graphic Travelogue. Noida, India: HarperCollins.

Murthy, Bharath. 2015b. Kushinagar: The Place where Buddha Died. Yahoo! News. $<$ https://in.news.yahoo.com/kushinagar--the-place-where-buddha-died-132041292. html $>$ (accessed 21 May 2015).

Murthy, Bharath. 2016. - Bharath Murthy. < https://bcomix.wordpress.com> (accessed 14 December 2016).

Natarajan, Srividya, S. Anand, Durgabai and Subhash Vyam. 2011. Bhimayana: Experiences of Untouchability. New Delhi: Navayana.

Nayar, Pramod K. 2016. The Indian Graphic Novel: Nation, History and Critique. London \& New York.

Omvedt, Gail. 2003. Buddhism in India: Challenging Brahmanism and Caste. London, New Delhi \& Thousand Oaks: Sage.

Orwell, George. 1949. Nineteen Eighty-Four. New York : Harcourt, Brace and Co.

Pathak, R.C. 1989. Bhargava's Standard Illustrated Dictionary of the Hindi Language (Hindi-English). Rev. ed. Varanasi: Bhargava.

Population by Religious Community. 2011. Census of India. $<$ http://www.censusindia.gov. in/2011census/C-01/DDW00C-01\%20MDDS.XLS> (accessed 25 April 2017).

Schodt, Frederik L. 1983. Manga! Manga! The World of Japanese Comics. New York: Kodansha.

Sen, Amartya. 2005. The Argumentative Indian: Writings on Indian History, Culture and Identity. New York: Picador.

Srinivas, Deepa. 2010. Sculpting a Middle Class: History, Masculinity and the 'Amar Chitra Katha' in India. New Delhi: Routledge.

Teo, Thomas. 2010. What is Epistemological Violence in the Empirical Social Sciences? Social and Psychology Personality Compass 4/5: 295-303. $<$ http://2012.ferienuni.de/ files/Teo2010EV2.pdf> (accessed 2 August 2016).

Tezuka, Osamu. 1972/2006. Buddha. Vol 1. New York: Vertical.

Thapar, Romila. 1989. Imagined Religious Communities? Ancient History and the Modern Search for a Hindu Identity. Modern Asian Studies 23 (2): 209-231.

The Edicts of King Ashoka: An English Rendering by Ven. S. Dhammika. 1993. <https:// www.cs.colostate.edu/ malaiya/ashoka.html> (accessed 12 December 2016).

The New Nationalism. 2016. The Economist. <http:/www.economist.com/news/ leaders/21710249-his-call-put-america-first-donald-trump-latest-recruit-dangerous $>$ (accessed 1 December 2016).

Trivedi, Divya. 2015. Morphing the Buddha. Frontline. $<$ http://www.frontline.in/books/ morphing-the-buddha/article7239186.ece $>$ (accessed 20 June 2015).

\section{Malini Roy}

Nezavisna znanstvenica, Frankfurt na Majni, Njemačka

Selbstständige Wissenschaftlerin, Frankfurt am Main, Deutschland

\section{Iščezli put budizma: vjerski nonkonformizam kao političko disidentstvo u suvremenoj Indiji}

U radu se analizira grafički roman The Vanished Path [Iščezli put], nedavno objavljen u izdanju indijske podružnice svjetskoga izdavača HarperCollinsa (2015), crtača stripova i 
filmaša Bharatha Murthyja. Podnaslovljen „grafički putopis“, The Vanished Path govori o hodočašću Murthyja i njegove supruge, novoobraćenika na budizam, kroz rodno mjesto te religije - sjevernu Indiju i Nepal, gdje dominira hinduistička vjeroispovijest i gdje je budizam s vremenom izgubio na popularnosti. Sam Murthy kao važan utjecaj navodi epsku seriju autora mangi Osamua Tezuke Buddha (1972. - 1983.), smještenu u razdoblje ranoga budizma. Međutim, The Vanished Path od Buddhe razlikuje interes za vjersku politiku suvremene Indije, definiranu nedavnim usponom hinduističkoga militantnoga nacionalizma. Provedena analiza pokazuje da vizualni tekst grafičkoga romana The Vanished Path predstavlja otvoreni poziv na rehabilitaciju rane budističke misli u suvremenoj Indiji, a istodobno neizravno staje u obranu dugovječne tradicije sekularnih vrijednosti na tome području. Ta tradicija uključuje prihvaćanje religijskih manjina. Rad se također osvrće na kreativnu interakciju u stripu i grafičkome romanu između dviju azijskih kultura nasuprot u kritici uvriježenome povijesnome i geopolitičkome povezivanju zapadnih zemalja i Indije.

Ključne riječi: hinduistički nacionalizam, povijest budizma, Indija, vjerski sukob, sekularnost

\section{Der verschwundene Weg des Buddhismus: religiöser Nonkonformismus als politisches Dissidententum im modernen Indien}

Den Untersuchungsgegenstand dieses Beitrags bildet der graphische Roman The Vanished Path (2015) des Comiczeichners und Filmregisseurs Bharath Murthy. In dem mit dem Nebentitel „Ein graphischer Reisebericht“ versehener Roman wird die Reise von Murphy und seiner Ehefrau als buddhistische Neubekehrte durch das Gebiet Nordindiens und Nepals beschrieben, das als Geburtsstätte des Buddhismus gilt, wo allerdings diese Religion an Popularität eingebüßt hat und wo sich der Hinduismus breit machte. Murthy selbst erklärt, unter großem Einfluss des vom Manga-Autoren Osamu Tezuka verfassten epischen Werkes Buddha (1972-1983) zu stehen, dessen Handlung in der Zeit des frühen Buddhismus spielt. Dennoch liegt der Unterschied zwischen Tezukas und seinem Werk in Murthys Interesse an der durch den jüngsten Aufstieg des hinduistischen militanten Nationalismus bestimmten Religionspolitik des modernen Indiens. Aus der im Beitrag vorgenommen Werkanalyse geht hervor, dass der visuelle Text des graphischen Romans The Vanished Path zwar zur Rehabilitierung des frühen buddhistischen Gedankenguts offen aufruft, zugleich aber die langfristig praktizierte säkulare Tradition in diesem Bereich verteidigt, wonach das Vorhandensein von religiösen Minderheiten akzeptiert wird. Im Beitrag wird gleichfalls auf die kreative Interaktion im Bereich des Comics und des graphischen Romans zwischen diesen zwei asiatischen Kulturen eingegangen, und zwar trotz der in der Kritik sehr oft vorkommenden geschichtlichen und geopolitischen Verknüpfung Indiens mit den westlichen Ländern.

Schlüsselwörter: Geschichte des Buddhismus, hinduistischer Nationalismus, Indien, religiöser Konflikt, Säkularität 